\title{
New Education Model as the Foundation of the State Economic Security
}

\author{
Olga Rudakova \\ Financial University under the Government of the Russian Federation \\ Moscow, Russia \\ E-mail: olrud@yandex.ru
}

\begin{abstract}
Modernization of economy would be largely driven by the availability of the brand new type of workforce. There is an acute gap between the market demand and the quality of the workforce available that inevitably leads to the fast knowledge obsolescence. Therefore, modern-day economic development requires conceptual advance in the quality of the workforce education. The article tackles the matter of the decisive factors for the intellectualization of the education, which would be based on analysis of the contemporary trends. It also arrives at a conclusion about the necessity to create an efficient mechanism for partnership and alignment between the state, science and business policies in the educational sphere. Failure to do so would result in a gradual decrease of the average quality of education, loss of responsibility, erratic decision-making and threat to national security.
\end{abstract}

Keywords-national security; intellectualization of education; educational model; human capital

\section{INTRODUCTION}

Human capital development is the key factor in the creation of the innovative economy. It is crucial at this moment in time to ensure creation of the new breed of professionals that are capable of organizational and technological upgrade of the economy. It is thus important to underline that Russia's national security would depend on the availability of the brand new workforce (with broadened professional lore), rather than quantitative parameters of the educational programmes.

\section{ECONOMIC DEVELOPMENT AND INTELLECTUALIZATION OF SOCIAL LABOR}

Intellectualization of social labor in the developed markets has become an inherent part of the state policy and is generally realized via three directions:

- creativity is the key quality of the workforce with the top requirements for professional knowledge (specialists, administrative personnel, workers, farmers, which represent up to $50 \%$ of the total workforce in such countries as USA, Germany and the UK);

- within professions with high level of templet actions (partially administrative personnel, merchandisers, retail staff - totaling up to $35 \%$ of the workforce) creativity becomes one of the required factors;

- within all other professions the level of monotonous, non-physical templet work is minimized - this group makes up to $30 \%$ of the total workforce.

Nowadays it is quite hard to challenge the fact that the speed of adaptation to the market needs and creative ways in promotion of goods and services are more important compared with the availability of conventional raw materials. This may be achievable via the implementation of the human resources development programmes inside a company. There is an acute gap between the market demand and the quality of the workforce available that inevitably leads to the fast knowledge obsolesce.

Thus survival of an individual (company or a nation) in the above-mentioned environment requires large investment in human capital: researchers state that subdivision of personnel into educated and non-educated steps in the foreground within the modern society, while the level of technological development in all spheres of the global economy demands high qualification of the workforce by default, leaving those without the necessary educational background astray.

It is crucial to take into account that the system of creation and transfer of knowledge has dramatically changed in the recent decades, implying that it is next to impossible to have a professional prepared within 5-6 years so that he or she would be capable in a given profession for a lifetime. It's been statistically confirmed that approximately $5 \%$ of theoretical and $20 \%$ of practical data is being renewed annually.

Modern professional must be prepared to fast adaptation to the ever-changing working conditions, being able to adhere to new technologies and self-education. The idea of ever-lasting education first appeared in the late 1970-s early 1980-s in the western economic thought: an average professional has to upgrade his/her professional education not less than once in every three years, with up to $45 \%$ of the workforce being constantly involved in the ongoing staff development programmes. 
The unit that is used by the US economists to evaluate the half-life of a worker's competence deterioration ${ }^{1}$ (i.e. a $50 \%$ decrease of competence due to advent of new information) shows that most of professions have the competence half-life of below 5 years, that, applied to the Russian educational system, means that a professional losses his/her competence earlier than he or she finishes higher education. This problem might be solved by moving to a lifelasting educational paradigm, whereas the basic professional education must be supported by the ongoing trainings, serving only as foundation, not the final destination of the educational process.

UNESCO distinguishes three processes in the international educational development at the moment:

- Increase in the number of students in the last decade of the $20^{\text {th }}$ century;

- Globalization and unification driven by advent of new telecommunication methods in all spheres of life have led to transparency and flexibility of education;

- The last 20 years saw considerable increase in the educational spendings on state level across the globe.

Tables 1-3 bear some key factual figures, characterizing the Russian educational system 2 .

Stable economic development requires high quality of the professional education, with the latter being the spearhead of the state activities. The system of education has a direct impact on the personality, way of life and subsequently in the development of the new professional workforce. The recent economic crises revealed relatively low competence level of the significant part of the workforce in Russia, with lack of emotional intelligence and psychological resilience being the key problems (and by no means low quality of workforce). Creativity, emotional intelligence were neglected in favour of the niche specialists with limited area of thought. Low quality and sometimes lack of systematic approach towards the development of human resources has resulted in the overall decrease in creativity and thus ability to adapt, diminishing their ability to compete on personal and corporate level.

\section{INTELLECTUALIZATION OF EDUCATION: THE NECESSITY AND WAYS TO ACHIEVE}

The necessity for intellectualization of education is driven by:

- role of education in the Russian society;

- adequacy of the Russian education to the global trends;

- new social requirements to the Russian education.

${ }^{1}$ Blinov AO, Rudakova OS The strategic objectives of Education reform based on the adaptation of advanced foreign experience // Universities for Tourism and Service Association Bulletin. №4 (19) P.87-94

${ }^{2} \mathrm{URL}$

http://www.gks.ru/wps/wcm/connect/rosstat_main/rosstat/ru/statistics/ population/education/\#
The first factor is linked to the necessity of formation of the new quality of the Russian economy and society. Intellectualization of education is thus aimed at making the national education adequate to the requirements of the modern economy, which is based on knowledge, as any person with multi-capabilities can easily adapt to most of the challenges.

The second factor requires an upgrade of the Russian education to mitigate its lagging behind the global pillars, namely:

- Increase of importance of human capital which currently constitutes $70 \%-80 \%$ of the national wealth of the developed countries - this is impossible without the urgent upgrade of the education of both young generation and the existing professionals;

- Constant development and vertical growth of the international economy that decreases the overall volume of low quality physical labour;

- Constant need for professional growth and reeducation driven by the boosted mobility of workforce triggered by structural shifts in the international economy;

- Broader options for political and social choice that adds new requirements to citizens;

- Growing intra-cultural cooperation, advent of the society based on information, which is much more tolerant and highly communicative;

New global problems which can be solved only through cooperation of the international community with contemporary way of thinking.

The third factor includes the formation of educated professionals with certain moral values and enhanced creativity which can effectively apply their knowledge when necessary, capable of collaboration on international level and being driven by mobility and developed sense of responsibility, the latter specifically applied on the future of Russia.

The modern concept of education ensures that everyone should have an opportunity (equal) to upgrade his/her education or qualification. Post-graduates must develop not only specific skills, relevant to his/her professional needs, but also acquire the ability to learn throughout the professional life, developing such qualities as communication, adaptiveness, self-reflection etc.

In order to achieve the above it is of paramount importance to upgrade the quality of the basic and additional professional education, since even the first-rate brand additional education would render void in case an individual lacks elaborate background. 
TABLE I. NUMBER OF HIGHER EDUCATIONAL ESTABLISHMENTS IN THE RUSSIAN FEDERATION (IN UNITS)

\begin{tabular}{|c|l|l|l|l|l|l|l|l|l|}
\hline & $\mathbf{1 9 9 0}$ & $\mathbf{1 9 9 5}$ & $\mathbf{2 0 0 0}$ & $\mathbf{2 0 0 5}$ & $\mathbf{2 0 0 8}$ & $\mathbf{2 0 1 0}$ & $\mathbf{2 0 1 3}$ & $\mathbf{2 0 1 4}$ & $\mathbf{2 0 1 5}$ \\
\hline State-owned & 514 & 569 & 607 & 655 & 660 & 653 & 578 & 548 & 530 \\
\hline Commercial & 0 & 193 & 358 & 413 & 474 & 462 & 391 & 402 & 366 \\
\hline Total & 514 & 762 & 965 & 1068 & 1134 & 1115 & 969 & 950 & 896 \\
\hline
\end{tabular}

TABLE II. VOLATILITY OF THE NUMBER OF STUDENTS IN THE STATE-OWNED AND COMMERCIAL EDUCATIONAL ESTABLISHMENTS IN THE RUSSIAN FEDERATION (IN THOUSANDS)

\begin{tabular}{|c|l|c|c|c|c|c|c|c|c|}
\hline & $\mathbf{1 9 9 0}$ & $\mathbf{1 9 9 5}$ & $\mathbf{2 0 0 0}$ & $\mathbf{2 0 0 5}$ & $\mathbf{2 0 0 8}$ & $\mathbf{2 0 1 0}$ & $\mathbf{2 0 1 3}$ & $\mathbf{2 0 1 4}$ & $\mathbf{2 0 1 5}$ \\
\hline Commercial & 0 & 135,5 & 470,6 & 1079,3 & 1298,3 & 1201,1 & 884,7 & 803,5 & 705,1 \\
\hline State-owned & 2824,5 & 2655,2 & 4270,8 & 5985,3 & 6214,8 & 5848,7 & 4762,0 & 4405,0 & 4061,4 \\
\hline Total & 2824,5 & 2790,7 & 4741,4 & 7064,7 & 7513,1 & 7049,8 & 5646,7 & $5209 ? 0$ & 4766,5 \\
\hline
\end{tabular}

TABLE III. NUMBER OF STUdENTS PER 10’000 OF POPULATION

\begin{tabular}{|l|l|l|l|l|l|l|l|l|l|l|}
\hline & $\mathbf{1 9 9 0}$ & $\mathbf{1 9 9 5}$ & $\mathbf{2 0 0 0}$ & $\mathbf{2 0 0 5}$ & $\mathbf{2 0 0 8}$ & $\mathbf{2 0 1 0}$ & $\mathbf{2 0 1 1}$ & $\mathbf{2 0 1 2}$ & $\mathbf{2 0 1 3}$ & $\mathbf{2 0 1 4}$ \\
\hline Total & 190 & 188 & 324 & 493 & 526 & 493 & 454 & 424 & 393 & 356 \\
\hline
\end{tabular}

Modern educational model implies creation of proper competencies and innovative mindset already at the level of basic education, with special accent on creativity and selfeducation on massive scale. This would require update of the existing methods and technologies on all levels of basic education so that a competitive and creative professional can be "bred" via personified professional educational programmes.

Innovative educational programmes must actively make use of new information technologies, progressive forms of education.

Contemporary business puts special emphasis on the creativity and human capital development: it is argued that every US\$35k invested in education in the US result in a return of exceeding US\$ $1 \mathrm{~m}^{3}$.

The final aim of use of new technologies in the educational process is the creation of environment where a professional individual is encouraged to have his/her personal traits developed on the basis of cross-cultural communication, critical thinking and rational behavior. The so-called learning-by-doing (case studies, role plays, projectbased learning) programmes provide an opportunity for the students to become trainees in real business institutions while bringing in new ideas and creativity to the employees.

Activation of the creative learning is determined by the deliberate activity of the tutor at stimulation of such forms of education that boost creativity, self-education and independence in the learning process in the students, which should culminate in the ability to take educated decisions.

Cognitive interest of students is the key driver behind such boost. Professional interest envisages use of methods and forms of tutoring that imitate the professional activities of the educated. We would like to underline that it is critical to implement compulsive approach towards activation of cognitive thinking and learning, that means that a student

${ }^{3}$ Blinov AO, Rudakova OS Innovative approach to management training for the modern economy // Economic Strategies, №4 (70), 2009. P.146-150 should be actively involved irrespective his/her own desire to do so.

This approach provides for development of creative thinking and prevents simple "remembering" of the information provided by the tutor, that eventually leads to a student becoming capable of adaptation to the ever-changing environment.

Post-graduates should be well-equipped with only those skills and knowledge that are relevant during a specific stage of a country's development. This is the only way to ensure return on investments into education. Thus the strategic aim of the Russian educational system is to create highly adaptive professionals that can easily meet all the challenges in the labor market.

Ill-developed educational strategy can bring much harm to a country's development: many specialists believe that advent of the Unified State Examination would replace the system that puts stress on the self-education, creative thinking and ability to adapt towards gambling in the multiple choice universe. Unified computer testing at universities seems to be leading to the similar dire consequences, as the new technologies should not be blindly used to replace all the methods and approaches developed in the past, thus removing the sense of continuity in the educational process.

A hefty portion of expense incurred in education is borne by the state budget of the Russian Federation (to ensure that professionals are prepared in accordance with federal standards).

As per this standard all specialist must have similar set of skills and knowledge. On the one hand this brings in a unified approach towards education and creates competition among higher educational establishments, however on the other hand diminishes the application of new methods that are required to meet demands of real-life business.

Though standards envisage both federal and regional components (the latter allowing the educational 
establishments to determine the set of additional educational methods to be applied), these flexibilities are insufficient.

It is high time to create a mechanism that would combine partnership of state, scientific and business approaches based on new forms of financing of education by means of diversification of the sources (that implies joint investment, public \& private partnership programmes, as well as development of brand new instruments for such financing, i.e. transfer of funds from investors to universities).

Investments into education is not only an important way to boost human capital in a country, but also a road map for future economic growth through broadening of professional sphere of interests of each single person and thus ensure better application of his/her skills and abilities in the everchanging global environment.

Thus statistics regarding the literacy and education level of population are one of the most important in the analysis of the quality of life in a given country. Strategic aim of education is to ensure constant absorption of new information for the sake of better life potential.

Without the educational leap the economy would be doomed to be teeming with millions of ill-educated, poorqualified and emotionally dead persons that would be easily replaced by various means of automatization, as lacking the ability to creative thinking.

Life-lasting education is one of the basic characteristics of the new educational model, with various modules and programmes available to every single individual to ensure long-term competitive position.

\section{CONCLUSION}

It is definitely impossible for a single individual to know everything and to be prepared for all possible trends, however a society that knows how to conduct self-education, creative society, can apply its potential in the economy of knowledge, taking responsible and not opportunistic steps for the benefit of the whole nation. Averaging however results in marginalization of workforce and makes it socially unstable and receptive to political opportunism that is a direct threat to national security.

\section{REFERENCES}

[1] Blinov AO, Rudakova OS The strategic objectives of Education reform based on the adaptation of advanced foreign experience // Universities for Tourism and Service Association Bulletin. №4 (19) P.87-94

[2] Blinov AO, Rudakova OS Innovative approach to management training for the modern economy // Economic Strategies, №4 (70), 2009. P.146-150

[3] URL:http://www.gks.ru/wps/wcm/connect/rosstat_main/rosstat/ru/stat istics/population/education/\# 